\title{
The future of Flemish social housing
}

\author{
Sien Winters · Marja Elsinga
}

Received: 27 May 2008/Accepted: 27 May 2008/Published online: 5 July 2008

(C) The Author(s) 2008

\begin{abstract}
Housing policy in Belgium and Flanders is directed mainly towards encouraging home ownership. Social housing in Flanders covers a share of $5.6 \%$ of the housing stock. This social rental sector is characterized as a safety net by some housing researchers and as a general model by others. During the 1990s and the first half of this decade social housing in Flanders became under discussion. The image of social housing that dominated then was one of increasing problems with tenants and neighbourhoods. Raising the income limits to get a better social mix was advocated by the sector and afterwards by policy as one of the solutions for these problems, meanwhile also improving the revenues of the housing associations. The political discourse however was very little supported by scientific knowledge. This contribution aims at clarifying the position of the Flemish social housing by describing the historical and regulatory context and presenting the results of the Housing Survey 2005. It dispels the misunderstanding that Flemish social housing is a residual model and explores different future models. One of the conclusions is that solving problems of the social rental sector may not occur at the cost of those who need affordable housing most.
\end{abstract}

Keywords Social housing $\cdot$ Housing policy $\cdot$ Flanders

\section{Introduction}

Belgian social housing has a history of more than 100 years. Since 1980 housing policy belongs to the responsibilities of the regions. In this article, we look at social housing in Flanders, the largest of the three Belgian regions.

\footnotetext{
S. Winters $(\square)$

Higher Institute for Labour Studies (HIVA), K.U. Leuven, Parkstraat 47, Bus 05300,

Leuven 3000, Belgium

e-mail: sien.winters@hiva.kuleuven.be

M. Elsinga

OTB Research Institute for Housing, Urban and Mobility Studies, Delft University of Technology,

Delft, The Netherlands

e-mail: m.g.elsinga@tudelft.nl
} 
Compared to many European countries, the share of social housing in the housing stock $(5.6 \%)$ in Flanders is limited. Social housing is supplied mainly by private organizations, which work within a rather tight regulatory system. Investments are largely subsidised by the Flemish government. The social housing supply is mainly targeted towards lower income households, which pay income-dependent rents.

Within Europe, one can observe social housing is evolving. Although social housing in different countries has very different histories, certain trends and discussions can be observed. There is a trend of privatization, social housing moves away from public and many countries are exploring public private partnership. Moreover, segregation and social mix are issues discussed in many European countries. Finally, in many countries there is a tension between providing social housing for long time local residents, and providing it to those in the greatest housing need (Whitehead and Scanlon 2007). Within this broader European scope, one can question what is the position of Flemish social housing and what are possible or desired future developments.

This article starts with a description of different definitions and models of social housing and the way the Flemish social housing sector is characterized until now Next a brief historical overview of social housing policy in Belgium and Flanders is given, the current debate on social housing in Flanders is briefly described and recent figures on the profile of Flemish social housing are presented. In a next section the Flemish social rented sector is positioned in the international context. The article ends with a discussion of policy options. This contribution is largely based on a research carried out for the Flemish government first half of 2005. The reason behind the study was the intention of the Minister of Housing to reform the regulatory framework of Flemish social housing. The researchers were asked to advise the Minister concerning demarcation of the target group, the allocation system, rent setting and the degree of local autonomy regarding rent setting and allocation. Complete results of the study are available in Winters et al. (2007).

\section{Models of social housing}

The term "social housing" covers a wide range of initiatives within Europe, aimed at good quality, affordable housing. Much has been written in the literature about the need and definition of social housing. Maclennan and More (1997) claim that social housing is needed when the socially desired needs for housing exceed the effectively desired demand for housing. In general, it is agreed that this means affordable housing for vulnerable groups. A further search of the literature produces various definitions of social housing (see, for example, Oxley 2000). What is noticeable is that views are far from unanimous. Thus, for example, social housing can refer to both renting and purchasing. The owner of those homes can be a public or private owner and can be looking to make a profit in his business management, or not. Moreover, the affordability of housing can be arranged by supply subsidies as well as demand subsidies. In the remainder of this article we hold the following definition: all rental dwellings allocated by need and not by market mechanisms.

Kemeny (1995) has developed a theory of the dynamics of rental systems in which he distinguishes two (rental) housing models that may arise simultaneously in different (groups of) countries: the dual and the unitary model. The dual model implies that nonprofit renting is separated from the private rental market by the government and is used as a safety net in the form of a strongly controlled public rental sector. Because access to the public rental sector is restricted to households with a low income and many households do not find the private rental sector with high rents and limited rental protection attractive, 
demand is steered strongly towards the owner-occupied sector. As an alternative to this model, Kemeny describes the unitary rental sector in which an independent nonprofit rental sector competes on the housing market with the profit rental sector and the owner occupation sector for the favours of broad layers of the population without specific government protection or support (that is without 'positive discrimination'). According to Kemeny the Flemish social housing sector should be characterized as a dual rental model.

According to Kemeny (1995), nonprofit landlords in a unitary rental market share the following characteristics: they receive no other government support than commercial landlords, they are mature and able to remain financially healthy, the regulative framework allows them to be in open competition with the commercial rental sector, the rents they charge follow the market and they have a wide target group. They issue is that there is competition with the commercial rental sector. Kemeny et al. (2005) further elaborated on the concept of the unitary market and they conclude that social housing can play three different roles in the rental market: in influencing role (Switzerland), a leading role (Sweden) and a dominating role (Netherlands).

Social housing has different shapes in different countries; social housing as a universalistic and a safety net model are distinguished for example. Within the universalistic model a difference can be made between social housing as for employees and housing for all (Czischke 2005; Whitehead 2007). Ghekière (2007) provides a typology for social housing in Europe. He distinguishes three concept. The first is the residual concept striving to cope with a clearly outlined social demand that is restricted to the most disadvantaged persons who are generally excluded from a housing market characterized by a strong predominance of home owner occupation and a non regulated private rental market. The second is the generalist concept. This implies targeting a social demand but to a larger extent of public intervention, this concept has an impact on the housing supply namely in terms of price and quality. The last concept is the universal one. This concept is intended to guarantee the housing supply for the entire population with both a complementary offer to what the market provides and the regulation of the entire housing market. Ghekière classifies the Flemish social housing sector as a generalist model. However, the Flemish social rental sector is developing towards a residual model (Ghekière 2007).

Between the models of Kemeny and Ghekière there is an overlap in criteria such as target group and role in the housing market, but there are also differences. Ghekière's (2007) definition of general social housing seems to overlap with what Kemeny calls influencing social housing in a unitary rental market. Moreover, the definition of the target group in the residual model (safety net) seems to be more strict than the Kemeny's (1995) definition of safety net of dual model. These two classifications enlighten the special position of the Flemish social rental sector and the way it is classified in comparative research. Kemeny qualifies the Flemish social rental sector as a dual model and a safety net, while according to Ghekière the Flemish social sector is a generalist model developing towards a safety net model. This contribution aims at further clarifying the position of the Flemish social rental sector.

\section{Social housing in Flanders}

\subsection{Historical overview of social housing policy in Flanders}

Belgian housing policy has its roots in the late nineteenth century and has been chiefly targeted, throughout its history, at promoting home ownership (see, e.g. Goossens 1982; 
Descamps 1997; De Meulder et al. 1999). Substantial premiums ${ }^{1}$ and tax incentives were awarded to prospective owners.

The social rented sector also originated at the end of the nineteen century, but the sector was mainly developed after the Second World War. ${ }^{2}$ Nonetheless, the social rented sector did not acquire such an important role in post-War reconstruction as it did in other European countries. During the period 1950-1995, 83\% of new construction in Belgium was carried out by private individuals. The social housing associations represented $16 \%$ of new housing construction. Of this, two-thirds were intended for sale and one-third for letting (Descamps 1997). Until 1960, no income limit existed for social rented homes. From then on, the target group was narrowly defined during some periods and during others very broadly (Goossens 1997; De Decker 2000). In 2005, 39\% of households in the private rental market complied the income criteria (Heylen et al. 2007).

From the 1980s on housing policy in Belgium became the sole responsibility of the three regions: the Flemish Region, the Walloon Region and the Brussels Region. Although housing policy in the three regions developed along the same principles, divergences concerning applied instruments, terminology and chronology can be observed since then (Hubeau 2002). The Flemish Housing Code (Vlaamse Wooncode-decree of 15 July 1997) laid down the main principles of Flemish housing policy. The constitutional right to decent housing became the starting point. Several new policy instruments were introduced. Remarkable was that Flanders shifted the emphasis from promoting property acquisition to supporting tenants. Whereas, in 1994, expenditure on behalf of tenants and owners was approximately the same, in 2003, the rented sector accounted for approximately three times as much. In terms of expenditure to benefit tenants, in 2003, 94.8\% went to investment support for social housing construction (Winters and Van Damme 2004) and the remainder to direct support for private individuals.

Nonetheless, the federal government also possesses important tools that have a significant impact on the housing market. For instance, the housing tax system benefits home owners many times larger than the budget which the Flemish government has available to pursue a housing policy. As a result, Flemish families are still strongly encouraged to purchase their own homes (Doms et al. 2001). Furthermore also rent legislation remained a federal power. Following Goossens (1997) this can be characterized as highly liberal legislation. Rent regulation is limited to sitting tenants. For new lettings, rents can be freely negotiated.

\subsection{Social housing organization, regulation and finance in Flanders}

Social rented housing in Flanders accounts for a market share of 5.6\%, while the ownership sector represents $74.4 \%$, the private renting sector $18.5 \%$ and $1.5 \%$ of the households is living free. The market share of social housing is higher in urban areas than in rural areas. Expressed as a share of the total rental sector, social housing amounts to less than a fourth (Heylen et al. 2007, Figs. 2005).

The largest part of social rented housing is supplied by private organizations. In 2006 these organizations let 136.659 social houses (VMSW 2007). Most of these have a long history in social renting. Today the largest shareholders are the municipal councils. The boards of directors consist mainly of municipal representatives. In 1997, within the

\footnotetext{
1 The main premiums were through the Moyersoen Act (1922) and the Detaye Act (1948).

2 In particular, the Brunfaut Act (1949) was a milestone.
} 
Housing Code, the social housing associations and their umbrella organization, the Flemish Housing Corporation (Vlaamse Maatschappij voor Sociaal Wonen-VMSW), ${ }^{3}$ were declared the preferred partners for the implementation of social housing.

The housing associations differ in extent. Of the 97 associations 15 own less than 500 dwellings and 24 have more than 1,000 dwellings (Lyben 2007). In the largest cities (Antwerp and Ghent) several associations are active. In smaller cities and rural areas most associations have their own territory covering more than one or many municipalities. The last years some mergers took place. These mergers are stimulated by policy aiming at a professionalization of the sector. The result of the operation is that the average number of dwellings per association rose from 1.150 in 2000 to 1.480 in 2006 (Lyben 2007).

The rental of social dwellings is regulated at Flemish level in the 'Social Rental Decree ('Sociaal Huurbesluit, Flemish government decree of 20 October 2000). This defines eligibility criteria and allocation rules, as well as rent setting. Income limits apply, depending on the family situation. Housing associations determine whether individual households fulfill the requirements and assign the dwellings, according to the priority rules laid down in the Social Rental Decree. Preferences of tenants can be taken into account, but little or no possibilities exist for taking into account specific local circumstances. The Decree also defines the formula for rent calculation. The main factors in the formula are the updated cost price of the dwelling and the income and family situation of the tenant. Although, at first glance, rent calculation is strictly regulated, associations have a certain degree of autonomy in rent setting. According to the financial needs of the association, they can raise rents.

Local authorities in Flanders have limited responsibilities in social housing. Some municipalities have their own social housing stock, but except from the largest cities the market share is small. The Flemish Housing Code made the local authorities responsible for coordinating local housing policy in general. But concerning social housing very few instruments for intervening are available. The most important instruments are land policy and the shareholding in housing associations.

Social housing in Flanders is still subsidized on an object basis. Investment in new construction, renovation and infrastructure (roads, parks etc.) is largely subsidized by the Flemish Region. Above social housing profits from VAT reduction. These object subsidies are converted into income dependent rents.

An interesting model in Flanders is offered by the Social Rental Offices ('Sociale Verhuurkantoren-SVKs'). These organizations rent dwellings on the private rental market and let these dwellings to vulnerable groups. Subsidies are limited to the operating costs of the SVKs. ${ }^{4}$ At the end of 2005, the number of dwellings let by SVKs was 3.032.

\subsection{The current debate in Flemish social housing}

During the 1990s and the first half of this decade social housing in Flanders became under discussion. The image of social housing that dominated then was one of increasing problems with tenants and neighbourhoods. Based on extensive document analysis, De Decker (2005) demonstrates that the discourse concerning social housing evolved from a local topic into a broadly supported consensus about the social tenant as a problem and social neighbourhoods as uninhabitable. In the early 1990s, according to De Decker, it was

\footnotetext{
${ }^{3}$ Until 1 July 2006 Vlaamse Huisvestingsmaatschappij (VHM).

${ }^{4}$ Recently, the rent subsidy (in fact a 'moving subsidy') is extented to (new) tenants of SVKs.
} 
mainly the influx of ethnic minorities which was regarded as problematic. Gradually, new problem categories were added: criminals, people committing social fraud, tenants who did not pay their rent. Later, the problem group was even further expanded to include vulnerable families, people on a minimum income and, ultimately, to low wages in general.

Various interested parties (directors of the associations, political parties, residents' organizations, etc.) have pointed out that the target group for social housing has shifted from traditional family types to the long-term unemployed, ethnic minorities, single people and single-parent families (see e.g. Cools 2004; VVH 2004, hearing of Flemish Parliament, 16 December 2002). The influx of weak groups in this context is being directly linked to the existence of livability problems and poverty is associated with inappropriate living behaviour-noise nuisance, vandalism, harassment. Virtually all political parties advocate raising the income limits in order to attract "better target groups" and to achieve a "social mix". The Vereniging van Vlaamse Huisvestingsmaatschappijen (Union of Flemish Housing Associations- $\mathrm{VVH}$ ) advocates wide autonomy concerning the allocation of social rented dwellings, so as to be able to turn away "risk tenants" or to to limit the influx of certain groups. The housing associations also propose the introduction of trial contracts or temporary contracts aiming to prevent problems with tenants (VVH 2004). A last point of criticism of the associations is their financial situation. The VVH claims that, as a result of rents being linked to incomes, the incomes of the social housing associations have fallen, which is not being compensated by a proportionally increased level of subsidy (VVH 2004).

On the other hand, the voices of vulnerable groups are also being heard. For instance, the welfare sector points out that insufficient numbers of homeless people are able to enter social housing (Van Menxel 2005; Lescrauwaet 2005). The Vlaams Overleg Bewonersbelangen (Flemish Occupants' Interests Consultative Body-VOB) has expressed criticism of the concept of "social mix" as a component of the allocation policy (Inslegers 2005). ${ }^{5}$

The Flemish Minister responsible for Housing is attempting to respond to some of the aforementioned problems. In the Policy Document 2004-2009, the Minister states that it must be possible, at the level of residential neighbourhoods, to achieve a balanced social mix, both within social housing and within the society as a whole, in order to provide a response to the local quality of life problems. An increase in the income limit is considered to give lower middle class access to the social housing market and simultaneously improve the financial situation of social housing associations. In addition the Minister announced the availability of more legal instruments to cope with social fraud and specific domicile fraud, harassment, rental property damage and rent arrears (Keulen 2004). At the time of writing this article, no final decision has yet been made.

Important to know at this point in discussion is that many of these statements were not supported by scientific knowledge. According to De Decker (2005), the discourse was based chiefly on incidents, formulated and fuelled by people with important social and political positions and eagerly adopted by the media. For some of the mentioned problems the 'Housing Survey 2005 ' is now providing new information.

\subsection{The profile of social housing in Flanders}

In 2005 for the first time a large housing survey was organized: 5.214 Flemish households were interviewed face-to-face concerning their current housing situation, housing costs and

\footnotetext{
5 The VOB is the umbrella organisation of Flemish landlords' unions, social letting offices and housing initiatives targeted at weak groups.
} 
housing needs (the 'Housing Survey 2005'), while a sample of 8.216 dwellings was inspected from the outside (the 'Housing Inspection 2005'). Both surveys provide a detailed picture of the housing situation in Flanders, which is extensively described in Heylen et al. (2007). It is important to notice that only inhabited dwellings are included in the survey.

Following the Woonsurvey 2005 Flemish dwellings mainly are one family dwellings. The share of apartments and studios amounts to only $20 \%$ of the housing stock. In social housing however, almost half of the stock (46\%) consists of apartments and studios. High rise buildings (here defined as more than five storey's) represent only a small share of the social housing stock: in rural areas only $2 \%$ of social dwellings can be found in high rise estates, in urban areas this share is $25 \%$. Compared to the rest of the Flemish housing stock, social dwellings are more recently built: $66 \%$ is built after 1971 while for the complete housing stock this is $45 \%$.

The quality of the social housing stock in general can be evaluated as rather good. Three indicators were examined.

Following an objectified and detailed screening ('Housing Inspection 2005') only $0.2 \%$ of the inhabited social dwellings is of substandard external quality, what is significantly less than the $0.5 \%$ for the owner-occupied dwellings and the $1.4 \%$ for the private rental dwellings. Substandard quality means that these dwellings have to be demolished or need a thorough renovation.

Based on an indicator for the physical condition of the dwelling that makes use of the meaning of the residents (indicator Vanneste et al. 2004; data 'Housing Survey' 2005) $56.2 \%$ of the social dwellings was evaluated as 'good'. Social housing qualifies better than the private rental sector $(45.9 \%)$, but not as good as the owner-occupied sector $(71.2 \%)$.

A third indicator takes into account the conveniences of the dwelling and the number of repairs needed as assessed by the residents (indicator Vanneste et al. 2004; data 'Housing Survey 2005'). For this indicator social housing performs better than the two other market segments. The share of dwellings having 'at least basic comfort' for social rental is $79.0 \%$, while this is $64.9 \%$ for the private rental sector and $76.0 \%$ for the owner-occupied sector. 'At least basic comfort' means that toilet and bathroom are available and not more than three repairs are necessary.

The 'Housing Survey' confirms former research results (see e.g. Pannecoucke et al. 2001) concerning the weak socio-economic profile of social tenants. This weak profile can be deduced firstly from income figures. Half of the social tenants has an income belonging to the first quintile of the distribution of equivalent income, $28 \%$ belongs to the second quintile.

Secondly it can be observed that several weak groups are overrepresented. Singles and one parent families in social housing have a share of resp. $39 \%$ and $16 \%$, while this is resp. $26 \%$ and $7 \%$ in the total population. Households of which the head is unemployed and sick or disabled in social housing represent resp. $14.6 \%$ and $8.8 \%$ against resp. $4.8 \%$ and $3.2 \%$ in the total population. And finally also older residents are overrepresented in social housing: for $36 \%$ of the households renting a social dwelling the head of the household is 65 years or older, while in the total population this is $28 \%$.

Whether there has been an influx of weaker groups in social housing during the last decades cannot be verified on an empirical basis. Due to a lack of data, the figures for 2005 can only be compared to 1999 data (Pannecoucke et al. 2001). This comparison shows the profile of social tenants has weakened in terms of income. The average equivalent income in constant prices of 2005 between 1999 and 2005 decreased from van resp. 970 euro to 913 euro. The share of households in the first quintile of equivalent income increased from 
$42 \%$ tot $50 \%$. But even from this evolution we cannot conclude that there has been an influx of weaker groups in social housing during the observed period. Unquestionably one reason behind the decreasing income is the ageing of the social tenants. The share of households with a head aged 65 years or older increased from $27.7 \%$ to $35.7 \%$. As well the share of unemployed as of sick or disabled heads of the family decreased, resp. from $16.3 \%$ to $14.6 \%$ and from $11.0 \%$ to $8.8 \%$. Drawing conclusions concerning the influx of weaker groups demands a more detailed analysis of social tenants data requiring preferably panel data.

Following the Housing Survey 2005 the average social rent is 258 euro per month, what is significantly less than the average private rent (431 euro). Of social tenants $41 \%$ pays less than 300 euro per month while this is the case for only $10 \%$ of private tenants. On top of these rents additional costs for heating, electricity, and maintenance of the building have to be paid, amounting to 120 euro for social tenants and to 127 euro for private tenants.

Despite these low rents affordability in social housing is not guaranteed. A possible indicator for affordability is the share of tenants that pay more than $30 \%$ of disposable income for rents. This is the case for $12.2 \%$ of social tenants, what is far below the $39.2 \%$ of private tenants. Based on data concerning the residual income affordability of social renting however is more problematic than of private renting. After paying rents social tenants have left 720 euro equivalent disposable income, while this is 929 euro for private tenants. The reason behind is the higher income of private tenants.

The relatively good housing quality and low rents in social housing explain why social tenants on average are very contented. Asked for their level of satisfaction with the dwelling $88.9 \%$ of social tenants replies to be 'satisfied' or 'very satisfied' (comparable with $80.0 \%$ of private tenants). The satisfaction with the neighbourhood however is slightly lower in social renting ( $86.7 \%$ is 'satisfied' or 'very satisfied') than in private renting (89.2\%), but still can be concerned as very good. The high level of satisfaction also results in a low tendency to move: $45 \%$ of social tenants reply that if they had the opportunity they in no case want to move. In the private rental sector this is $29 \%$.

These new findings confirm the results of former research from Pannecoucke et al. (2001) but do not fit the general image of social housing as it appeared in the public discourse. The existence of problems in social housing cannot be ignored but should be seen in correct proportion.

\section{The Flemish social rented sector in an international perspective}

How does the Flemish social rental sector compare to social renting in other countries? This section describes Flanders in an international perspective by comparing it with five other countries; some of them with small social rental sectors (Ireland, Spain and Germany), others with larger sector (UK and Netherlands) (see Winters et al. 2007). The aim is to describe different features of the social rental sector in these countries, searching for the differences and signs of dual and unitary models.

\subsection{Organization and size of the social rental sector}

As described in Sect. 2, a social rented sector can have both a private and a public nature. Table 1 provides a summary of the nature of the social rented sector in six countries. In Ireland, public landlords have exclusive rights; in the Netherlands private organizations 
Table 1 The social rented sector in six countries: ownership, participation, financial objective, market share and responsibility for housing allocation

\begin{tabular}{|c|c|c|c|c|c|}
\hline $\begin{array}{l}\text { Country and type } \\
\text { of owners }\end{array}$ & Ownership & Participation & $\begin{array}{l}\text { Financial } \\
\text { objective }\end{array}$ & $\begin{array}{l}\text { Market } \\
\text { share }\end{array}$ & $\begin{array}{l}\text { Housing } \\
\text { allocation }\end{array}$ \\
\hline \multicolumn{6}{|l|}{ Flanders } \\
\hline Housing associations & Private & Public & Non-profit & 6 & Central \\
\hline Local authorities & Public & Public & Non profit & & Local \\
\hline SVK & Private & Public & Profit & & Local \\
\hline Ireland & Public & Public & Non-profit & 9 & Central \\
\hline \multicolumn{6}{|l|}{$U K$} \\
\hline Council & Public & Public & Non-profit & 14 & Local \\
\hline RSL & Private & Private & Non-profit & 6 & \\
\hline Company/person & Private & Private & Profit & & \\
\hline Germany & Private & & & & \\
\hline Company/person & Public & Private & Profit & Together: 5 & Local \\
\hline Municipality & & Public & Non-profit & & \\
\hline Netherlands & Private & Private & Non-profit & 35 & Local \\
\hline \multicolumn{6}{|l|}{ Spain } \\
\hline Municipality & Public & Public & Non-profit & Together: 3 & Local \\
\hline Company/person & Private & Private & Profit & & \\
\hline
\end{tabular}

Source: Winters et al. (2007)

have exclusive rights. The housing associations in Flanders are in a unique position: they are private organizations that provide for public participation through shareholding by the local authorities. Even more unique are the SVKs. It is public organizations letting privately owned dwellings. In other countries, such as the UK, Germany and Spain, more parties are involved in the letting of social rented dwellings, not only public or private nonprofit organizations, but also profit-making parties. The social rented sector is therefore not linked to an owner, but to the system within which dwellings are let.

In the Netherlands and the UK, the social rented sector occupies a larger market share, i.e. $35 \%$ and $20 \%$ of the housing stock, as shown in Table 1 . In both countries, we see a trend towards a decline in social rented dwellings owned by the government. In the Netherlands, the municipal housing companies have virtually disappeared and, in the UK, the number of RSLs (registered social landlords) is gradually increasing. These currently manage $6 \%$ of the UK housing stock. One difference between the UK and the Netherlands is that the social rented sector fulfils a safety net function in the former case and, in the latter, it is accessible to many target groups.

In Spain, Germany and Ireland, as in Flanders, the social rented sector is modest in scope, varying between $3 \%$ and $9 \%$. However, major differences exist between the social rented sectors in these countries. In Germany and Spain, a dynamic social rented sector exists, which is managed by private landlords. Dwellings are built with a subsidy and kept affordable for a certain period and they are also the subject of dwelling allocation rules. At the end of this period, these dwellings are free. In Ireland, the social rented sector fulfils the function of a social safety net and the sector is owned by local authorities. The social rented sector in the Netherlands has an unclear character; on the one hand a maximum income criterion applies, on the other hand priority rules apply to weak groups. 
Responsibility for housing allocation varies. In Ireland, the central authority plays a prominent role in housing allocation. The Housing Act prescribes that local authorities must draw up a scheme of letting priorities and submit it to the minister for approval. This distribution of tasks bears close resemblance to the situation in Flanders, where the regional authority has established strict rules for the allocation of all social rented dwellings from the housing associations. Any deviations have to be centrally agreed. Social dwellings owned by OCMWs (local authorities) and the private dwellings of SVKs are allocated locally.

In the other countries studied, local actors are given a major role. In Germany, the Länder can further specify the target group for subsidised dwellings in their subsidy schemes. Municipalities can control landlords via the subsidies they allocate and the emergency rule. The arrangements for this differ locally. In Spain and the UK, the local authority is responsible for housing allocation. In the Netherlands, housing allocation is the shared responsibility of the local authority and the housing corporations.

\subsection{Subsidies and rent}

Based on the objective of social housing, financing is always to be based on affordability of the dwelling for the social tenant. For tenants with a low income, this means that the rent has to be squeezed in one way or another. We are talking in this context about the difference between the cost-effective rent and the social rent. The cost-effective rent is the rent that is needed to cover all costs which the landlord incurred for the dwelling. The social rent is the price paid by the social tenant.

One-first potential option is that the government bear full financial responsibility and therefore make up all of the difference between the social rent and the cost-effective rent. This can be through both a subject subsidy to the tenant and an object subsidy to the landlord, who then converts this into a reduced rent for the tenant. The effect for the tenant is the same in both cases, at least in so far as the rent is legally established.

The alternative is that the landlord is made financially responsible. He is then assumed to generate income himself in order to charge a social rent to lower income groups. The incomes can come from letting to higher income groups, from the sale of dwellings or from financial reserves accumulated in the past.

In all the countries listed in Table 2 an object subsidy for social rented dwellings is applied, a subsidy that can take various forms and makes a social, non-market compliant rent possible. The only exception to this is the Netherlands, where the object subsidies were abolished in 1995 and housing corporations are themselves deemed to subsidise the construction of social rented dwellings from the available capital or through other activities that generate revenue.

In addition to the object subsidies for the dwellings, for low income groups an incomedependent subsidy is also available in the UK, the Netherlands, Germany and Spain. Ireland and Flanders are exceptions in this case. In these countries, the income-dependent rent in the social rented sector can be considered an alternative to the subject subsidy.

The systems of determining rent in the countries under discussion are very diverse. In Flanders and Ireland, the rent depends mainly on the income of households; in Germany it now depends on the market rent, in the UK and Spain on the cost price and, in the Netherlands, on the quality assigned to a dwelling via the housing valuation system and the policy of the landlord. Flanders and Ireland are remarkable in this context. In these two countries, the rent and therefore the rental income depend on the income of the tenants. An 
Table 2 The social rented sector in six countries: subsidising and rent

\begin{tabular}{|c|c|c|c|c|}
\hline $\begin{array}{l}\text { Country and type } \\
\text { of owners }\end{array}$ & $\begin{array}{l}\text { Object } \\
\text { subsidy }\end{array}$ & $\begin{array}{l}\text { Housing } \\
\text { allowance }\end{array}$ & Rent & $\begin{array}{l}\text { Financial } \\
\text { dependence on } \\
\text { tenants' incomes }\end{array}$ \\
\hline Flanders & & & Income- and cost- & Housing \\
\hline Huisvestingsmaatschappijen & Yes & $\mathrm{No}^{\mathrm{a}}$ & price dependent & association \\
\hline OCMW & Yes & & & \\
\hline SVK & $\mathrm{No}^{\mathrm{b}}$ & & & \\
\hline Ireland & Yes & No & Income-dependent & Council \\
\hline $\begin{array}{l}\text { UK: council } \\
\text { RSL } \\
\text { Company/person }\end{array}$ & Yes & $\begin{array}{l}\text { Yes, for both social } \\
\text { and private sectors }\end{array}$ & Cost-price dependent & - \\
\hline $\begin{array}{l}\text { Germany } \\
\text { Company/person } \\
\text { Municipality }\end{array}$ & Yes & $\begin{array}{l}\text { Yes, for both social } \\
\text { and private sectors }\end{array}$ & Market price dependent & - \\
\hline Netherlands & No & $\begin{array}{l}\text { Yes, for both social } \\
\text { and private sectors }\end{array}$ & $\begin{array}{l}\text { Depending on } \\
\text { regulation and market }\end{array}$ & - \\
\hline $\begin{array}{l}\text { Spain: } \\
\text { Municipality } \\
\text { Company/person }\end{array}$ & Yes & & Cost-price dependent & - \\
\hline
\end{tabular}

Source: Norris and Shiels (2004) and Scanlon and Whitehead (2004)

a No general scheme, only subsidies for moving

b SVKs receive subsidies for their intermediation function

increase in the influx of low-income groups results in a lower rental income. In both countries, financial problems exist with a number of social landlords. In Ireland, this is a public problem; in Flanders this is a problem with the private housing associations. However, regional policy in Flanders was also forced to find solutions. A 'social letting' subsidy was awarded three times to housing associations housing low income families and facing financial problems.

\subsection{The position of Flemish social housing}

This overview of six countries shows the variety within social housing in six countries. Referring to the models in Sect. 2 we must conclude that the Irish social rental sector shows most similarity with the safety net model, as well according to Kemeny's dual model as to Ghekiere's residual model: the sector is public, is reserved to the lower income groups and the control of allocation and rent setting at the central level. The Dutch social rental sector comes closest to the unitary model or universal model: is financially independent, rent policy is market rent driven, and social housing is more or less competing with the commercial rental sector. ${ }^{6}$ The other four countries are in between.

Flanders is closest to the Irish social rental sector. There are however differences, that can be considered as deviations from the dual model or residual model. Features of the dual model that can be recognized in Flanders are the rather limited market share of social housing, the use of income limits and priority rules for vulnerable groups, the central regulation of rent determination and of allocation. On the other hand, the Flemish social

${ }_{6}$ There is discussion on the issue of whether there is a level playing field. 
housing is not completely public, as is the case in the dual model. Within the classification of Ghekière, shortly after the Second World War, the Belgian social housing model can be seen as an example of the general model. Since than, as Ghekière describes an evolution from a general model towards the residual model can be observed, starting from the introduction of income limits in 1960. In 2005 the households in the social rental sector have a weak socio-economic profile compared with the ownership sector and the private rentals sector. Whether the sector is further evolving towards a residual sector cannot be verified due to a lack of data. Comparison of data for 1999 and 2005 revealed a decrease in average income, that however is probably resulting from the ageing of the sitting tenants, rather than from an influx of households with lower incomes. In any case, the Flemish social housing cannot be classified as a pure example of the residual model, since access is not restricted to the most disadvantaged groups.

\section{Policy options}

What future can be seen for Flemish social housing? A first option is a more consequent choice for the safety net model. This would among other things imply a stronger selectivity concerning the target group. With a social housing stock amounting to $5.6 \%$ of total housing stock not all needs for affordable and decent housing are met.

How many households are in need for housing assistance? Estimating the extent of this group demands for standards concerning housing affordability and housing quality. Generally agreed standards for Flanders are not available. In Winters et al. (2004) several affordability standards are discussed. The 'residual income measure' is evaluated as the most appropriate method, but cannot be applied by lack of a minimum income standard for Flanders. As an alternative we make use of a rent to income ratio, assuming that households spending more than $30 \%$ of their disposable income on rents face affordability problems. The $30 \%$ standard can be justified since it is generally used in Flemish housing literature and applied by financial banks for evaluating the borrowing powers of clients. Part of the households paying more than $30 \%$ however has an income that is high enough to rent a decent dwelling. Starting from the median rent for a private dwelling of decent quality (400 euro) we observe this is the case for the third, fourth and fifth income quintile. For this reason these quintiles are excluded from the estimations. Also households owning a house are excluded, assuming that this house can be sold and can provide the household with the necessary income to afford a decent rental house.

Next we need a quality standard. Therefore we use the indicator 'physical condition of the dwelling' (Vanneste et al. 2004; see above). Dwellings evaluated as 'bad' or 'very bad' are considered as not complying with the requisite housing quality.

Under these conditions the number of households in need of housing support (that can be met either by social housing or by housing allowances) can be estimated on 176,000. Limited to the first income quintile the estimate is 100,000 households. Remarkable is that the first number is close to the number of households that according to their income and family situation comply with the actual legal conditions for renting a social dwelling (estimated on 180,000).

These figures indicate that the actual social housing stock in Flanders is far too small to house all families in need of housing support. Satisfying these needs by supplying social housing would require a substantial extension of the sector. Ascribing new tasks to the private commercial sector in social housing could offer opportunities. For this purpose fiscal or other financial incentives (e.g. VAT reductions) can be considered. An 
intermediating role of housing associations or SVKs in this case would be preferable in order to avoid negative selection.

Complementary, redistribution of the actual housing stock favouring the lowest incomes and the most vulnerable groups could be an option. This can be done for example by decreasing income limits, driving out better-off residents or limiting the term of contracts. This option however probably will not be acceptable to the housing associations since it has an impact on its receipts. A consequent choice for the safety net model would therefore imply full responsibility of the regional government in filling the gap between social rents and costs.

A social housing system with a broader defined target group sometimes also is advocated for Flanders. Indeed there are opportunities for social housing meeting the needs of some more wealthy groups actually facing problems on the housing market. As in other European countries for example the ageing of the Flemish population creates new housing needs. A drawback of the large share of owner-occupied houses is that many older persons stay living in their own house lacking basic amenities and conveniences. Being eligible for comfortable social dwellings in the neighbourhood of services would offer these older persons an attractive alternative and could postpone the use of residential care. An advantage of an enlargement of the target group could be a broader support of society for social housing. If not only low income families will be eligible and if rents are set on or even above the level of market rents new revenues come available for financing the social housing system as a whole or for contributing to housing of vulnerable groups. Above the admittance of higher income groups could offer opportunities for developing integrated housing projects and mixed communities.

There are however also many obstacles for bringing this enlarged model into practice in the Flemish case. The most important obstacle is that the actual social housing stock is too small to admit new groups without excluding vulnerable groups even more than is already the case now. Another important obstacle for enlarging the target group is the actual fiscal system. As long as home ownership is fiscally advantaged as much as it is now, households that can afford it will buy or build their own house and the possibilities to make profits out of letting social houses will remain limited. A last obstacle could be European legislation. Under EU legislation only Services of a General Economic Interest (SGEI) may receive state subsidies. Broadening the target group might lead to conflicts with this legislation.

\section{Discussion}

Flemish social housing today cannot be simply pigeon-holed into one of the models. The result presented here provide most support for classification of Ghekière (2007): the Flemish social rental sector is still a general model but current developments can be seen as a shift towards the residual model. The priority ruling for weak tenants point in this direction, the central supervision of allocation and the priority given to home ownership are signs for such a model. On the other hand, there are clear signs of what could be called a unitary or a general model. The survey results show that the social rental sector is of relatively good quality and appreciated by the tenants, even better then the private rental sector. Finally, the Flemish social sector is not a safety net targeting primarily the most vulnerable people.

Segregation and social mix as well as the tension between providing social housing for long time local residents, and providing it to those in the greatest housing need are issues occurring in several European countries (Whitehead and Scanlon 2007). This article shows 
that these issues also play a very important role in current discussions in Flanders. Different future policies are considered in this article and provided with their advantages and drawbacks. Different directions for social housing imply different policy instruments and different responsibilities at the varies levels. To make sustainable decisions on social housing it is important to have clear ideas on the future model of social rental housing in Flanders, to make sure that solving problems of the social rental sector is not at the cost of those who need affordable housing most.

\section{Epilog}

Shortly after finishing this article, the Flemish government decided about new rules for allocation and rent setting in social housing and about a new system of object subsidies. Income limits after all were not increased, but the housing associations are assigned more flexibility in allocation, allowing some degree of social mix in neighbourhoods that can be identified as problematic. Rent setting is changed in order to increase affordability of social housing for the lowest income groups. The new subsidy system includes incentives for a more efficient service delivery, while subsidies should better bridge the gap between income and expenses of the housing associations. Due to a lack of simulations, the outcome of these changes at this moment remains unclear.

Acknowledgements The authors are grateful to the referees for their useful comments.

Open Access This article is distributed under the terms of the Creative Commons Attribution Noncommercial License which permits any noncommercial use, distribution, and reproduction in any medium, provided the original author(s) and source are credited.

\section{References}

Cools, H.B. (2004). Sociale huisvesting. Een vergelijkend vierstedenonderzoek rond verdraagzaam samenleven (Social housing. A comparative four-city study of tolerant cohabitation). Brussels: Politea.

Czischke, D. (2005). Social Housing in the EU Time for legal certainty for local authorities, social housing providers and millions of European households. Cecodhas, Brussels: Report to the European Commission.

De Decker, P. (2000). Wie geniet van de overheidsuitgaven in Vlaanderen? (Who benefits from government spending in Flanders?). Ruimte en Planning, 20(1), 8-35.

De Decker, P. (2005). In sommige sociale woonblokken zou ik mijn konijnen nog niet durven steken. Over sociaal huren, de creatie van een reputatie en haar gevolgen (I would not dare put my rabbits in some social housing blocks. On social letting, the creation of a reputation and its consequences). In P. De Decker, L. Goossens, \& I. Pannecoucke (Eds.), Wonen aan de onderkant (pp. 283-318) Garant.

De Meulder, B. et al. (Eds.). (1999). Over de plaats van de volkswoningbouw in de Vlaamse ruimte (On the place of public housing construction in the Flemish space). In Ministry of the Flemish Community (Ed.), Huiszoeking (pp. 10-86). Brussels: Ministry of the Flemish Community.

Descamps, L. (Ed.). (1997). Het Sociale-Huisvestingsbeleid vanaf WOII tot heden. Van missie tot resultaten: de basisgegevens (Social housing policy from WW2 to the present. From mission to results: the basic data). In Flemish Housing Corporation (Ed.), Bouwstenen van sociaal woonbeleid (pp. 2182). Flemish Housing Corporation, Brussels.

Doms, K. et al. (2001). Op zoek naar eigendom. Onderzoek naar de overheidssteun voor eigenaars van woningen (In search of ownership. Research into government support for owners of dwellings). Leuven: HIVA-K.U.Leuven.

Flemish Parliament (16 December 2002). Hearing on the social mix and the quality of life in social housing. Report on behalf of the Commission for domestic affairs, housing and urban policy, published by Veerle Heeren, Session 2002-2003. Document 1498 (2002-2003) No. 1. 
Ghekière, L. (2007). The development of Social Housing in the European Union; when general interest meets Community interest, Summary of the Publication. Dexia Editors: Paris.

Goossens, L. (1982). Het sociaal huisvestingsbeleid in België. Een historisch-sociologische analyse van de maatschappelijke probleembehandeling op het gebied van het wonen (Social housing policy in Belgium. A historical-sociological analysis of dealing with social problems in the area of housing). Leuven: Faculty of Social Sciences-K.U.Leuven.

Goossens, L. (Ed.). (1997). De slinger van de selectiviteit. De onzekere lotgevallen van de doelgroepen van het woonbeleid in België (The pendulum of selectivity. The uncertain fates of the target groups of housing policy in Belgium). In Flemish Housing Corporation (Ed.), Bouwstenen voor sociaal woonbeleid (pp. 253-294). Brussels: Flemish Housing Corporation.

Heylen, K., Le Roy, M., Vanden Broucke, S., Vandekerckhove, B., \& Winters, S. (2007). Wonen in Vlaanderen: de resultaten van de Woonsurvey 2005 en de Uitwendige Woningschouwing 2005. Brussel: Departement RWO-Woonbeleid.

Hubeau, B. (2002). Hoofdstuk 1. Algemene inleiding en institutioneel kader: de Vlaamse Wooncode (nog niet) op kruissnelheid? In B. Hubeau (Ed.), Vijf jaar Vlaamse Wooncode: het woonbeleid (nog) niet op kruissnelheid? (pp. 3-77). Die Keure: Brugge.

Inslegers, G. (2005). Plannen voor een minder sociale huur (Plans for a less social rent) (20 pp). VOBNieuwsbrief-April 2005: VOB, Extra Collection.

Kemeny, J. (1995). From public housing to the social Market, rental policy strategies in comparative perspective. London: Routledge.

Kemeny, J., Kersloot, J., \& Thalmann, P. (2005). Non-profit housing influencing, leading and dominating the unitary rental market: Three case studies. Housing Studies, 20(6), 855-872.

Keulen, M. (2004). Vlaams Woonbeleid. Beleidsnota 2004-2009 (Flemish Housing Policy. Policy Document 2004-2009), 41 pp.

Lescrauwaet, D. (2005). Thuislozen krijgen geen voet aan huis in de sociale huisvesting (The homeless cannot get a foot in the door of social housing) In P. De Decker, L. Goossens, \& I. Pannecoucke (Eds.), Wonen aan de onderkant (pp. 437-445). Garant.

Lyben, H. (2007). De sociale huisvesting in beweging (Social housing on the move), presentatie voor de Studiedag over de toekomst van de sociale huisvesting in Vlaanderen, Vlaams Parlement. In Presentation at the Conference on the Future of Social Housing, 21 June 2007.

Maclennan, D. \& More, A. (1997). The future of social housing: key economic questions. Housing Studies, 12(4), 531-547.

Norris, M., \& Shiels, P. (2004). Regular National Report on housing developments in European countries, synthesis report, Ireland. Department of the Environment, Heritage and Local Government.

Oxley, M. (2000). The future of social housing: Learning from Europe. IPPR, s.1.

Pannecoucke, I., et al. (2001). Profiel van de sociale huurder en subjectieve beleving van de realisaties van de sociale huisvesting (Profile of the social tenant and subjective perception of the achievements of social housing). Antwerp: OASeS.

Scanlon, K., \& Whitehead, C. (2004). International trends in housing tenure and mortgage finance. London: London School of Economics.

Van Menxel, G. (2005). De ultieme onderkant: de thuisloze in het vizier (The ultimate underside: the homeless under the spotlight). In P. De Decker, L. Goossens, \& I. Pannecoucke (Eds.), Wonen aan de onderkant (pp. 157-194). Garant.

Vanneste, D., Thomas, I., \& Laureyssen, I. (2004). Fysische staat van de woning (Physical state of the dwelling). Ruimte en Planning, 24(4), 12-36.

VMSW (2007). Jaarverslag 2006 (Annual Report 2006). Brussel: VMSW.

VVH (2004). Visietekst: de toekomst van de sociale huursector (Vision text: the future of the social rented sector)

Whitehead, C. (2007). Privatisation of housing in Europe: Challenges for social housing providers. In D. Czischke (Ed.), Current developments in housing policies and housing markets in Europe: Implications for the social housing sector, Colloquium Proceedings of the first Colloquium. Brussels.

Whitehead, C., \& Scanlon, K. (2007). Social Housing in Europe. London School of Economics and Political Science, London.

Winters, S., Elsinga, M., Heylen, K., Haffner, M., Tratsaert, K., Van Damme, B., et al. (2007). Op weg naar een nieuw Vlaams sociaal huurstelsel?. Brussel: Ministerie van de Vlaamse Gemeenschap, Departement RWO.

Winters, S., Heremans, F., Elsinga, M., Marchal, A., Vandekerckhove, B., \& Van Steen, G. (2004). Op weg naar een Vlaamse huursubsidie on way to a Flemish housing allowance? Kenniscentrum voor Duurzaam Woonbeleid, Leuven. 
Winters, S., \& Van Damme, B. (2004). Op zoek naar eigendom. De resultaten van twee HIVA-onderzoeken naar overheidssteun voor eigenaars van woningen samengevat (In search of ownership. The results, summarised, of two HIVA studies into government support for owners of dwellings). In Ministry of the Flemish Community (Ed.), Wonen onderzocht 2000-2004 (pp. 155-176). 